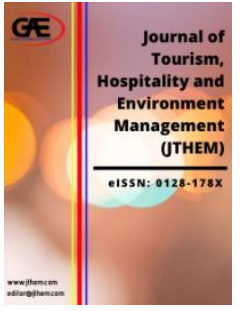

\author{
JOURNAL OF TOURISM, \\ HOSPITALITY AND \\ ENVIRONMENT MANAGEMENT \\ (JTHEM) \\ www.jthem.com
}

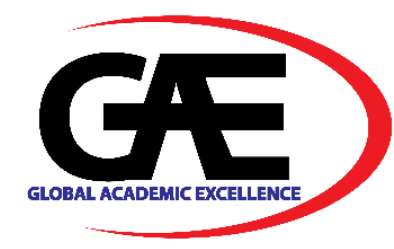

\title{
ARCHIPELAGO MUSICAL ELEMENTS IN ANANDA SUKARLAN'S WORK AS PART OF BUILDING INDONESIAN IDENTITY
} \author{
Ina Raseuki ${ }^{4}$, Viktor Ganap ${ }^{5}$ \\ 1 Pengkajian Seni Pertunjukan dan Seni Rupa, Universitas Gadjah Mada, Indonesia \\ Email: kartini.rm.m@mail.ugm.ac.id/kartini.manalu@uhn.ac.id \\ $2 \quad$ Pengkajian Seni Pertunjukan dan Seni Rupa, Universitas Gadjah Mada, Indonesia \\ Email: hendrik.1.s@mail.ugm.ac.id/hendrik.simanjuntak@uhn.ac.id \\ 3 Pengkajian Seni Pertunjukan dan Seni Rupa, Universitas Gadjah Mada, Indonesia \\ Email: lono_simatupang@yahoo.com \\ $4 \quad$ Penciptaan dan Pengkajian Seni, Institut Kesenian Jakarta, Indonesia \\ Email: nyakraseuki@pascasarjanaikj.ac.id \\ $5 \quad$ Fakultas Seni Pertunjukan, Institut Seni Indonesia Yogyakarta, Indonesia \\ Email: victor.ganap@yahoo.com \\ Corresponding Author
}

Kartini Ruth Maduma Manalu ${ }^{1}$, Hendrik Leonard Simanjuntak ${ }^{2}$, Lono Lastoro Simatupang ${ }^{3 *}$ Nyak

\section{Article Info:}

\section{Article history:}

Received date: 18.10 .2021

Revised date: 25.10 .2021

Accepted date: 07.11.2021

Published date: 01.12.2021

\section{To cite this document:}

Manalu, K. R. M., Simanjuntak, H. L., Simatupang, L. S., Raseuki, N. I., Ganap, V. (2021). Archipelago Musical Elements In Ananda Sukarlan's Work As Part Of Building Indonesian Identity. Journal of Tourism Hospitality and Environment Management, 6 (26), 58-74.
Abstract:

This study aims to examine the contribution of Ananda Sukarlan as a composer who is serious about building an Indonesian identity through the use of various Indonesian musical elements as material in composing piano and vocal works. How composers arrange various musical aspects that can work in a composition is the focus of this research. The study of musicology is used as an approach to dissect various aspects of the musical used, such as; melody, harmony, texture, tonality, scale, rhythm, timbre. Archipelago musical elements are a fundamental aspect in composing works that have 'new values' and 'different tastes' because they have uniqueness or characteristics. The complexity of the compositional techniques used in the preparation of the work shows a high level of creativity in producing vistuosic works. His works have become a repertoire for recitals, competitions, and music concerts for Indonesian and foreign pianists and soloist singers. Studying the works of Ananda Sukarlan indirectly also understands the musical diversity, the beauty of the region and the rich history of Indonesian culture. 


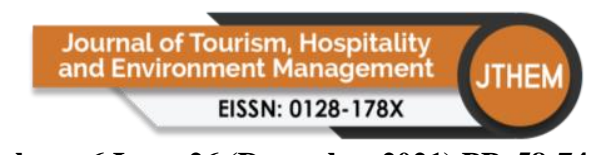

Volume 6 Issue 26 (December 2021) PP. 58-74 DOI 10/35631/JTHEM.626004

\author{
DOI: $10.35631 /$ JTHEM.626004. \\ This work is licensed under $\underline{\mathrm{CC} B Y} 4.0$ \\ (ㄷ)(i) \\ Keywords: \\ Identity, Ananda Sukarlan, Archipelago Musical, Works
}

\title{
Introduction
}

Archipelago is a word that is related to many aspects, including; history, geography, art and culture which are positioned in terms of 'glory' and 'greatness'. Reviews about the archipelago itself have been widely discussed by previous researchers, for example; van der Kroef (1951) provides various information on the use of the term 'Indonesia' in historical contexts; Cheuse (2002); and provide how to read the archipelago through various perspectives from several researchers; Jarir and Khairiah (2018) who looked at the history of the archipelago based on Wallace's theory based on plant, animal, and ethnographic types. Therefore, this study does not discuss too much about aspects of the archipelago related to history, geography, and art in the past context related to religion, trade, power, and artistic practices. However, this research is more directed to examine the use of Indonesian musical elements by composers in the preparation of vocal and piano musical works in the context of 'modern' which is believed to be part of building the identity of 'Indonesian classical music'.

Identity in work is related to the composer's activity in recognizing himself as part of the heterogeneous culture in which he grew up; composers who understand the richness and diversity of Indonesian musicals as a source of inspiration for their work; and composers are able to identify, empower, and expand existing compositional concepts in order to manifest ideas in their work. These three activities are related and inseparable parts in a recurring series that occurs at all times in the composition of vocal and piano musical works. Parekh (2007) says "essentially identity refers to how one identifies oneself in relation to others; announce and affirm to ourselves who we are; and how we position ourselves in the relevant areas of life". The concept of Parekh's identity is in line with the opinion of Hargreaves et al (2002) which states that the pattern of musical preferences possessed by an individual is closely related to identity. This preference pattern can be described as a 'music taste' which is an integral part of a person. Musical tastes vary from one individual to another due to several influencing factors, such as: (1) age level; (2) the level of music training: (3) aspects of cognitive style and personality; (4) the idea of 'cultural sense'; and (5) public taste.

The efforts made by Ananda Sukarlan in building an Indonesian identity can be seen in the concept of compiling vocal and piano music by expanding compositional techniques and governance in the presentation of works. Expanding compositional techniques can include utilizing various musical materials sourced from traditional musical idioms and folk songs spread from Sabang to Merauke. The selected musical material becomes the main basis for building vocal and piano works. In addition, the level of creativity of the composer is a determinant of the success of a work because it is related to the ability to elaborate various musical materials. The composer's experience and preference patterns are also an important part of considering all aspects of music to work well, for example; when is the time for Indonesian musical idioms to be placed in a work, how can the fragmentation of melodies or the merging of musical material sourced from several songs be put together in a composition.

The governance of the presentation of the work is also important because the message to be conveyed can be conveyed well to the listeners. Therefore, Ananda Sukarlan as a composer and pianist is open to collaborating or collaborating with other parties so that the continuity Copyright (C) GLOBAL ACADEMIC EXCELLENCE (M) SDN BHD - All rights reserved 


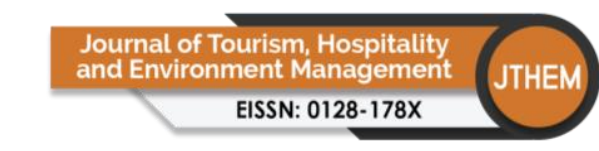

Volume 6 Issue 26 (December 2021) PP. 58-74

DOI 10/35631/JTHEM.626004

and presentation of the music performed is interesting and inspiring. Ananda Sukarlan has a central role in determining the theme of the concert and selecting the repertoire to be performed. In addition, Ananda Sukarlan also opened an open space for talented young Indonesian musicians to take part in playing his various works at the concert performance. Ananda Sukarlan's expertise as a composer and pianist is certainly not in doubt, but on the other hand we must not forget how the composer's ability to explore and collaborate with the Directorate General of Culture of the Ministry of Education and Culture of the Republic of Indonesia. The similar frequency between Ananda Sukarlan and the Directorate General of Culture in advancing Indonesian culture is reflected in the implementation of music performances held in the last two years. Even during the pandemic-19 situation, all planned performance programs were able to run well. Another support given by the Directorate General of Culture is to finance Ananda Sukarlan's competition in 2020 and 2021. However, this collaboration in organizing music performances can also be interpreted as a medium for the government. It also promotes tourist attractions and historical sites that are full of Indonesian religious and educational values and are well worth a visit.

There are two research questions that are the focus of the research. First, how is the composer's creativity in managing various aspects of Indonesian musicals as part of building an Indonesian identity? Second, how does Ananda Sukarlan build an Indonesian identity through the existence of the presentation of works?

\section{Literature Review}

Based on the study of literature, the authors obtain various data and facts showing that research on vocal and piano compositions by Indonesian composers is still relatively small. Therefore, it is not surprising that we encounter difficulties in finding out information about how the development of Indonesian vocal and piano music. This may be very different when looking for information on the development of Baroque, Classical, Romantic, and Modern vocal and piano music. Another question that arises about Indonesian vocal and piano music is: how is this Indonesian composer's vocal and piano music placed in the history of music? How did the Indonesian composers' vocal and piano compositional styles develop? and how are the concepts related to the composition of Indonesian composers? Some of these questions are actually urgent to be researched so that these works can be mapped and positioned according to compositional and historical styles.

Several previous studies related to vocal and piano music provided us with information which was then used in positioning this research. Rasmindarya (1999); Tjaroko (2007); Yunita (2012); and Mohammed (2016) emphasize nationalism, love for the homeland and the influence of lied in the development of seriosa songs. However, they have not discussed the processes that occurred before seriosa was introduced and how it developed in the current context. Several studies related to piano works include; Indonesian Piano Composition in History of Music; Discourse on Indonesian Piano Composition for Music Education; and Indonesian Composer's Piano Work in the Piano Education Curriculum which discusses the compositions of Indonesian composers from the point of view of musicology and music education. The discourse on the works of Indonesian composers in the historical trajectory of the piano and their use in music education is complementary to the world of music education in Indonesia and at the same time encourages future researchers to conduct research studies related to their works. Simanjuntak, Simatupang, and Ganap $(2019 ; 2021)$ 


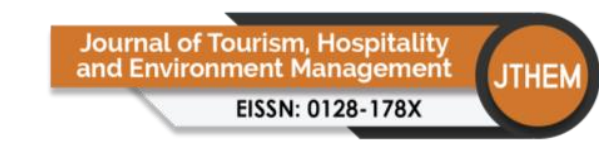

Volume 6 Issue 26 (December 2021) PP. 58-74 DOI 10/35631/JTHEM.626004

Through this literature review, the author would like to confirm that the research "Archipelago Musical Elements in Ananda Sukarlan's Work as Part of Building Indonesian Identity" is a new research topic and has never been reviewed by previous research. As a new study that aims to reveal how various elements of the archipelago are used in building Indonesian identity, the author uses the Beard and Gloag (2005) approach on musicology as a process of study, investigation and reflection. The various elements of the archipelago that Ananda Sukarlan uses in the preparation of his work are related to a long history in which the material is part of the daily life of the supporting community. In line with the opinion of Willams (1988) that history is a continuous and connected process from the past to the present, therefore the historical aspect is a separate consideration for composers to understand and then create it in various ways. Creation is the key word because in this area various aspects have been integrated and internalized within the composer. The musical experience (study and performance) that the composer went through and the cultural realm also collaborated in forming a musical composition that has an Indonesian identity. The composer's creativity with all the considerations taken cannot be separated from the cultural realm that inspires him and then the work is returned to the community to test its existence and how the community can accept it or even give birth to new models in terms of form, style, or genre.

\section{Methodology}

Indonesia-centric is a concept that builds Indonesia evenly and is not only oriented to the island of Java. This development concept provides broad opportunities for each region to be able to develop all the potential and diversity possessed by each region to realize mutual prosperity. The concept of Indonesia is centric in its application by building new tourist destinations in various regions and not only focusing on one or two specific areas, such as; Bali and Yogyakarta. The political favors carried out by the government by building new tourist destinations are a real and partisan step to improve the economy of the local population and the various effects that accompany it. The provision of large funds and the central role of the Ministry of PUPR are the main 'keys' in ensuring the successful development and management of new tourist destinations. In this study, there are two new destinations that the author chose to describe the development of this program, namely; Labuan Bajo Destinations in East Nusa Tenggara and Lake Toba Region in North Sumatra.

The concept of Indonesia-centric in the art of music is the utilization and use of various elements of the archipelago's musical to be the main part in the preparation of vocal and piano musical works with Indonesian characteristics. To see Ananda Sukarlan's creativity in the preparation of his work, the author conducted a study of two works, namely; Kama represents vocal works, and Rapsodia Nusantara no. 1 represents a piano piece. A musicological study approach is the choice to explore the extent to which various musical elements are organized and how they can all work in one composition. The composition of Kama is reduced and divided into several organizations, for example; aspects of melody, harmony, texture, form, and rhythm. This performance pattern can find out how a melody or harmony is composed, developed and formed. Likewise, the work of Rapsodia Nusantara no. 1 uses the same pattern with a different approach because the composer uses musical synthesis in the composition of the work. Therefore, melody analysis focuses on the grouping of certain elements, fragmentation of the melody, and the synthesis of elements in one unit of time.

The Indonesian-centric concept in musical performances is to provide space for performing musical works composed by Indonesian composers. Ananda Sukarlan is one of the Indonesian 


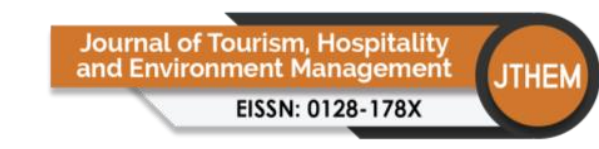

Volume 6 Issue 26 (December 2021) PP. 58-74 DOI 10/35631/JTHEM.626004

composers who collaborated with the Indonesian government for music performances, vocal competitions and piano competitions. Several performances carried out by Ananda Sukarlan, especially in the last two years, are a series of events that combine two interests, namely; (1) declaration of composer Ananda Sukarlan's musical works and introducing talented young Indonesian musicians; and (2) promoting Indonesian tourist destinations to the wider community. Ananda Sukarlan's collaboration with the Ministry of Education, Culture, Research, and Technology in organizing vocal and piano competitions is a form of the state's presence to maintain the continuous development of Indonesian musicians with achievements.

\section{Development of New Indonesian Tourist Destinations}

The Indonesian government's policy in the tourism sector has received a large portion in the last seven years, this is indicated by a change in the government's perspective or mindset in developing the tourism sector. The Indonesian government realizes that building new tourist destinations in various regions in Indonesia is one of the best ways to grow new economic centers; create jobs, and increase local economic growth and local government. The development of new tourist destinations is part of the government's effort to provide various options or alternatives for tourists who want to visit Indonesia. The uniqueness of the region becomes a strength in the development of new tourist destinations, such as; artistic traditions, festivals, food, dance, music, language and religion. In addition, various historical buildings, relics of the past, are an important part in the development of sustainable tourism because they are full of religious, glorious, social, artistic, aesthetic, and educational values. The development of new tourist destinations is also art of supporting Indonesia's already iconic tourist destinations with Bali and Yogyakarta tourist destinations.

The development and arrangement of new tourist destinations by prioritizing the strength, distinctiveness, and preservation of regional heritage is one of the efforts to maintain Indonesianness in a broad context as well as to fortify itself from modernity. Timothy and Boyd (2003)'s statement about the reasons why cultural heritage is preserved is the focus of the government to maintain nationalism, preserve collective impressions, explore various sciences and education, preserve artistic values, aesthetics, and environmental diversity. At the same time, the ideals of the Indonesian people regarding the realization of community welfare can be encouraged through a supportive economic ecosystem. Cultural heritage can be a means and a place to improve the economy of local communities by many interrelated aspects.

The biggest challenge in developing and structuring new tourist areas is that it requires large funds. Zhang's (1992) statement regarding the lack of funds in conservation and heritage management in developing countries is a fact that cannot be ruled out. On the one hand, public institutions in charge often hinder conservation and management efforts (Henson, 1989), and tourist sites located near the National Capital receive more attention and other areas are marginalized. (Myles 1989) These various problems are considered by the Indonesian government in calculating and budgeting the allocation of the required funds. Therefore, the priority scale is taken in the context of developing and structuring new tourist destinations that can be completed considering the Indonesian nation as an archipelagic country and has great tourism potential and is spread from Sabang to Merauke. The government carefully considers the policies taken so that the new tourist areas that have been determined can be carried out in accordance with the time, the budget provided, and the goals that are expected to be achieved. Caution in making policies is needed so that no tourism development and arrangement work is neglected. 


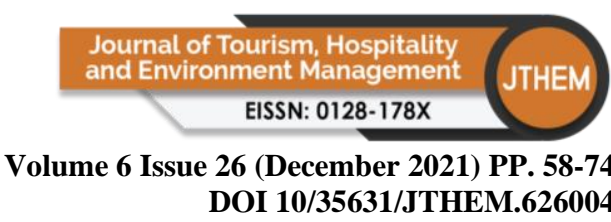

Speech by the President of the Republic of Indonesia, Joko Widodo (Jokowi) at the Kompas 100 CEO Forum on November 28, 2019, firmly gave his support and commitment to the development of new tourist destinations in Indonesia. The President has decided on ten new tourist destinations that are the government's priorities, and for the initial stage will build five new tourist destinations, namely; Mandalika, Labuan Bajo, Borobudur, Lake Toba, and Manado. (BPMI Presidential Secretariat, 2019). The Ministry of Public Works and Public Housing (PUPR) is given the task of being the spearhead or the leading sector in the development of new tourist destinations by constantly building cooperation and coordination with various related parties, both at the central and regional levels.

The extent to which the implementation of the development of new tourist destinations that have been carried out by the Ministry of PUPR can be seen in the following two examples. First, Labuhan Bajo was built with the concept of maximizing all the potential of the region along with its natural wealth. For example, the construction of Puncak Waringin which is about one kilometer from Komodo Airport is a strategic location to be developed. One of them is to build the Main Building which functions as a lounge (lounge); souvenir center, and viewing deck. In addition, the construction of kiosks complete with toilets, prayer rooms, weaving areas, public open spaces equipped with amphitheaters, and parking areas are other means to support tourism. Smooth transportation and connectivity is also a concern of the government by building roads, sidewalks, drainage, and structuring pedestrian supervision. In addition to Puncak Waringin, the government has also managed the Batu Cermin area by building a number of facilities such as; Batu Cermin Cave Building which consists of a plaza, auditorium, gift shop, information center, management office, and toilets. In addition, the PUPR Ministry also built an amphitheater, cultural houses, parking areas, and hiking trails to the caves. (Public Communication Bureau of the Ministry of PUPR, 2021; Handayani, 2021)

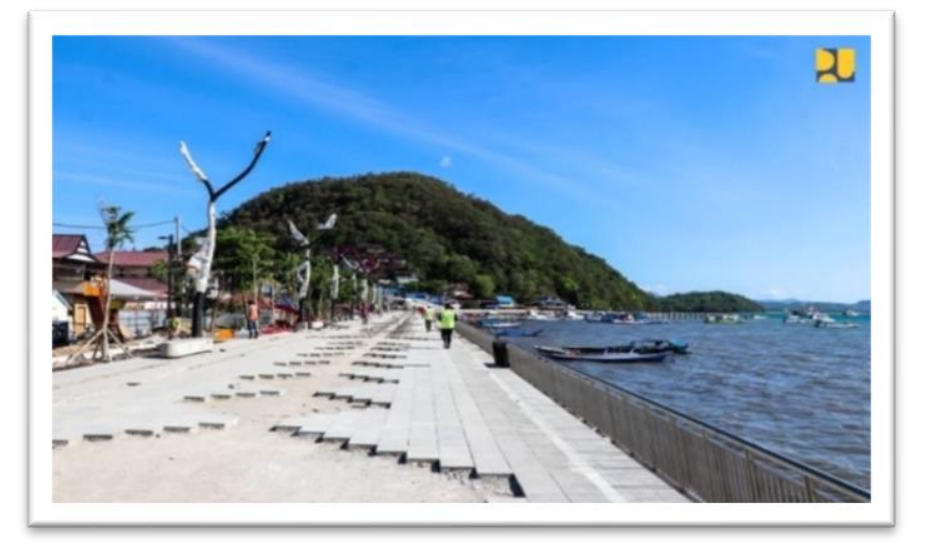

Figure 1: Marina Beach Waterfront Area - Pramuka Hill Source: Ministry of PUPR, 2021.

Second, Lake Toba Destinations as a priority tourism. The PUPR Ministry has allocated a budget of IDR 167.5 billion to build tourism residential facilities. The construction of tourism residential facilities by improving the quality of community houses along the tourism corridor can also be a homestay for tourists who visit and want to enjoy the hospitality of the residents. Corridor arrangement and homestay program are adjusted to local characteristics and wisdom. A total of 1,765 units were built along the corridor in the Lake Toba area and in six districts (Toba, Samosir, Simalungan, Humbang Hasundutan, North Tapanuli, and Dairi). This development is expected to encourage increased visits by domestic and foreign tourists. In Copyright (C) GLOBAL ACADEMIC EXCELLENCE (M) SDN BHD - All rights reserved 


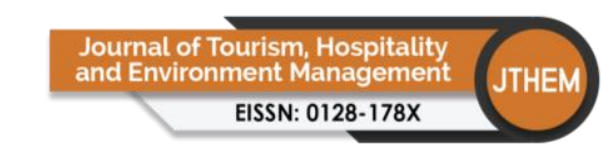

Volume 6 Issue 26 (December 2021) PP. 58-74 DOI 10/35631/JTHEM.626004

addition, road infrastructure and clean water facilities were also built to support government programs. (Petriella, 2020) The progress of infrastructure development in the Lake Toba tourist area has reached $97.6 \%$. Some of the completed area management work on Lake Toba are; (1) structuring Ulos Huta Raja and Huta Siallagan Villages in Samosir Regency; (2) Samosir Batak Traditional House or Ruma Gorga in the Huta Raja area; (3) Huta Siallagan Village is a village which is famous for its stone courts; (4) Samosir Island as one of Lake Toba's destinations is famous for its natural beauty and cultural uniqueness, including the traditional manufacture of Ulos woven fabrics from North Sumatra. Ulos weaving production activities featuring local wisdom are also the main attraction for domestic and foreign tourists; (5) the arrangement of Parapat Free Beach in Simalungun Regency includes; beach arrangement, construction of public open space, and arrangement of gates; (6) other supporting infrastructure for settlements, such as: construction of a final waste disposal site in Sidikalang, Dairi Regency, drinking water treatment plant in Karo Regency, wastewater treatment plant in Parapat, construction of pipelines in Paranginan, and construction of toilets in Dairi Regency. (Handayani, 2021)

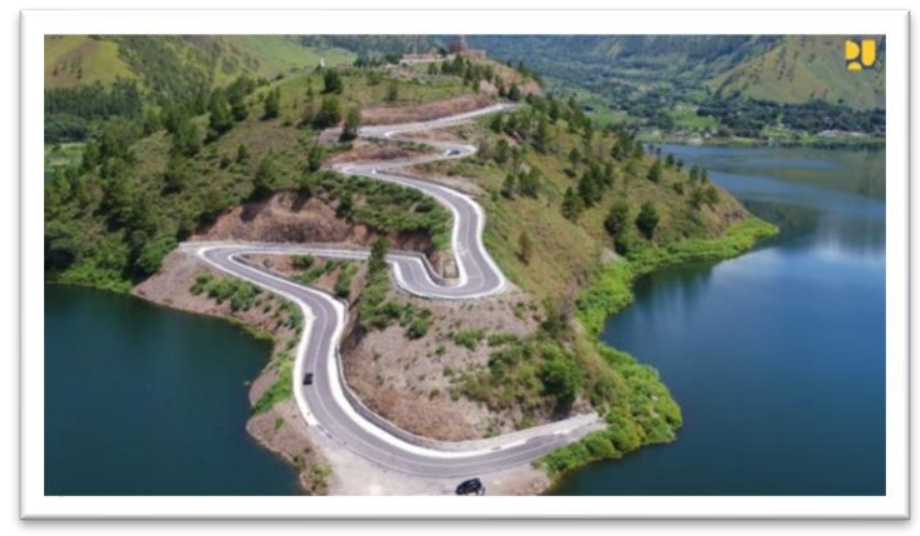

Figure 2: Construction of A Spiritual Tourism Access Road to The Jesus Statue Which Is Located on The Peak of Sibea-Bea Hill, Samosir Regency.

Source: Ministry of PUPR, 2021.

\section{Elements of Nusantara Music in Building Indonesian Identity}

Ananda Sukarlan conducted experimental practices on various idioms of Indonesian music and regional music in the preparation of musical works for piano and vocals. This idiom of Indonesian musicals and regional music is the main source for building new works that have an Indonesian character. Indonesian idioms and regional music have different expressive powers in terms of harmony, texture, melody, and rhythm. The composer's creativity is the main aspect in the preparation of the work so that the composition of the music composed can be accepted by the wider community, appreciated, and fulfills the pianistic and vocalization aspects.

Creativity in composition is certainly influenced by various factors, such as: educational background; musical experience; mastery of compositional techniques; understand the character of Indonesian idioms and regional music; and the ability to bring 'added value' or 'newness' from the previous form. Therefore, creativity is not understood as an activity of 'imitating' certain idioms or melodies, but most importantly the ability of the composer to expand the existing 'wall' or concept of composition. The idioms of the archipelago and the melodies of folk songs are important aspects to build national identity and also the identity of the composers themselves. This view is in line with the opinion of Csikszentmihalyi (1999) 
about the existence of new works (which in this case are piano and vocal compositions) due to the interaction process between composers and the cultural realm. The new works composed by Ananda Sukarlan have novelty in the context of materials, concepts, ideas, and identities. Therefore, the works of Ananda Sukarlan became the mainstream in the development of Indonesian classical music. Seeing this reality, it is not surprising that Ananda Sukarlan's works have become the preferred repertoire for pianists and soloist singers, both domestically and abroad. In addition, musicologists also began to pay great attention to the work of Ananda Sukarlan. Musicologists make Ananda Sukarlan's work the object of their research, both for undergraduate, master, dissertation, and research with other schemes.

As mentioned in the previous section, Ananda Sukarlan's works that became the object of this research were two works, namely Rapsodia Nusantara No. 1 which represents a piano piece and Kama which represents a vocal piece of music. These two works are interesting to analyze, both from the aspect of using the musical elements of the archipelago and the creativity of the composers. Rapsodia Nusantara No. 1 is the first composition designed by a composer based on an Indonesian folk song. This work is complex in terms of virtuoso piano technique and composition.

Rapsodia Nusantara No. 1 was prepared using inversion, retrograde, tonality and polymeric techniques. Elaboration of Indonesian musical material has been played by composers since the beginning of the bar in the form of fragmentation of the melody and rhythm of the song "JaliJali". The fragmentation of the melody and rhythm is placed on the up beat in beat 2, this is different from the song "Jali-Jali" which starts from the first beat. Although this work is placed in a neutral key signature or understood in $\mathrm{C}$ major tonality, the composer actually started this work from 5 flats $(\mathrm{Db})$.

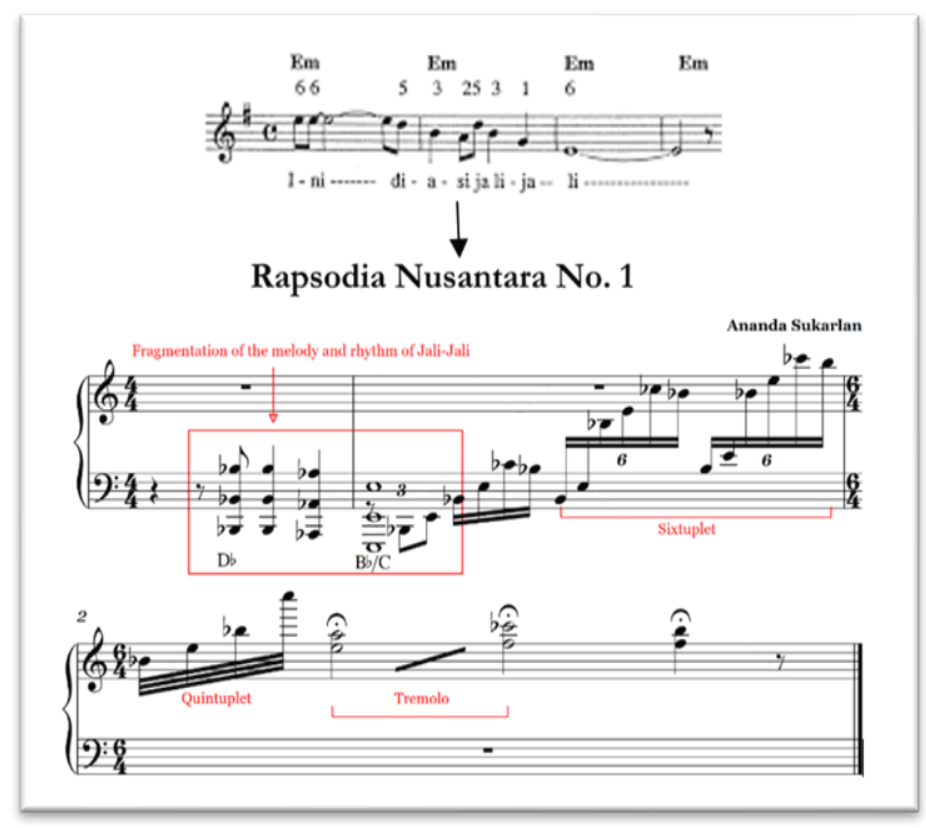

Figure 3: Fragmentation Analysis of The Melody and Rhythm Of "Jali-Jali" Source: Rapdosia Nusantara No 1-5 (Sukarlan, 2011) 
This pattern is voiced again at measures 3-4 in a different key, namely Db to Ab7(b5). Measures 5-9 are sequential repetitions of the previous pattern. The fragmentation of the song "KicirKicir" is voiced from measures 12-16 starting with parallel octaves and parallel quints arranged in descending order until the melody enters the F\# tone (the mi note in the key of D major). Melody and rhythm are augmented and diminuented, fast-moving harmonic changes have implications for the blurring of the tonality used (such as the use of Schoenberg's inversion and retrograde).

Structure of Rapsodia Nusantara No. 1 using free forms. Part A 1-23 bars at a moderato tempo and using 4/4, 6/4, 4/4, and 6/4 polymers. The melodic and rhythmic fragmentation of the song "Jali-Jali" in bars 1-9, 21-22 and the song "Kicir-Kicir" in bars 10-20 are used interchangeably. Part B is 24-50 with an Alla Marcia Funebre tempo and using 4/4, and 6/4 polymers. For the first time the composer used the entire melody of the song "Kicir-Kicir" by making some adjustments to the aspects of melody, rhythm, accompaniment and harmony. The bars of 2431 are arranged in $\mathrm{Bb}$ major tonality with octave accompaniment that moves according to scale intervals. Entering measure 33-50, the composer elaborated the melody of the song "Jali-Jali" with a multi-tonality approach where in one bar there are two different tonality when referring to the original melody of the song "Jali-Jali".

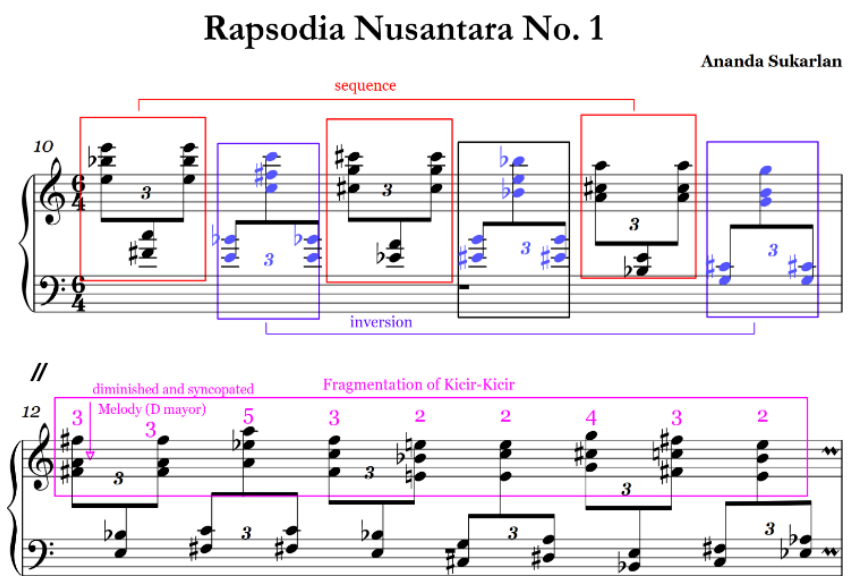

Figure 4: Analysis of The Compositional Technique "Kicir-Kicir"

Source: Rapdosia Nusantara No 1-5 (Sukarlan, 2011)

This is interesting to analyze and then we can use as part of the technique of composing new songs. Key changes that occur so quickly, often obscure the original melody. For example, in the 33-34 bar, the composer uses $\mathrm{Bb}$ or la and $\mathrm{Ab}$ notes or sol notes which are included in the $\mathrm{Db}$ major tonality. But on the beat when the bar 33 immediately changes to the key of $\mathrm{C}$ major. The composer did not choose the $\mathrm{F}$ or mi notes of $\mathrm{Db}$ major, but the $\mathrm{E}$ or mi notes of $\mathrm{C}$ major. For measure 34, the composer repeated the tonality changes in Bb major, mi [D], re [C] and la $[\mathrm{G}]$ notes. This change in tonality takes place along the 33-50 bar.

Part $\mathrm{C}$ is 51-68 with a maestoso tempo and uses a 4/4, 2/4, and 6/4 polymer. The composer reelaborated the melody of the song "Kicir-Kicir" and used polytonality. Part D in measures 6896 is arranged with subito presto tempo and 4/4, 2/4, and 5/4 meters. At 68-72 the composer uses counterpoint, syncopation, and E Phrygian mode (elaboration on the four notes E, G, B, and C). In measures 73-99 still using the counterpoint technique, but the tonality is included in the key of E minor harmonics. This section is an elaboration of the melody of the song "Jali- 


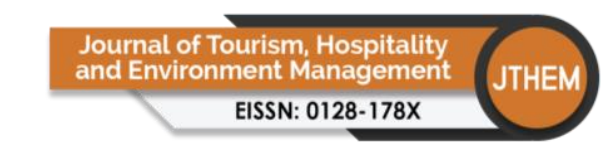

Volume 6 Issue 26 (December 2021) PP. 58-74

DOI 10/35631/JTHEM.626004

Jali" which is arranged in parallel octaves. Part E in bars 100-114 still continues the octave parallel technique and the elaboration of the material for the song "Jali-Jali". Slow and great tempo (largo-maestoso) became the composer's choice to close the work of Rapsodia Nusantara No.1.

Kama is a vocal composition with piano accompaniment arranged based on the use of Indonesian materials, namely the pentatonic scale as the basis for developing melody, harmony, and texture. Associated with the rhythm and function of the instrument in the gamelan is manifested by the composer in two different rhythms in the key of $G$ and key of $F$ (beer 1135). Of all Ananda Sukarlan's works, Kama is the only work that is entirely done with the development of archipelago materials. The basic pentatonic scheme used is 1-3-4-6-b7 and then along with its rotation. This scheme in Kama's work is: $\mathrm{Db}-\mathrm{F}-\mathrm{Gb}-\mathrm{Bb}-\mathrm{Cb}-\mathrm{Db} ; \mathrm{F}-\mathrm{Gb}-\mathrm{Bb}-$ $\mathrm{Cb}-\mathrm{Db}-\mathrm{F}$; Gb-Bb-Cb-Db-F-Gb; Bb-Cb-Db-F-Gb-Bb, and Cb-Db-F-Gb-Bb-Cb.

In addition, the harmony produced by this scheme is unique because of its approach to the composition of the harmony of western music traditions. Therefore, we do not find any correlation or strength of the progression of traditional harmony as harmony functions in the context of western music. If we refer to the traditional harmony approach, the pentatonic scheme used in Kama's work produces two chords, namely; subdominant and submediant chords. However, in the rotation system this is not absolute, because the position has changed (as a reverse chord). Kama is composed of 3 rotations of the pentatonic scheme, thus likely prompting the composer to give this work a 2 flat $(\mathrm{Bb})$ key signature.

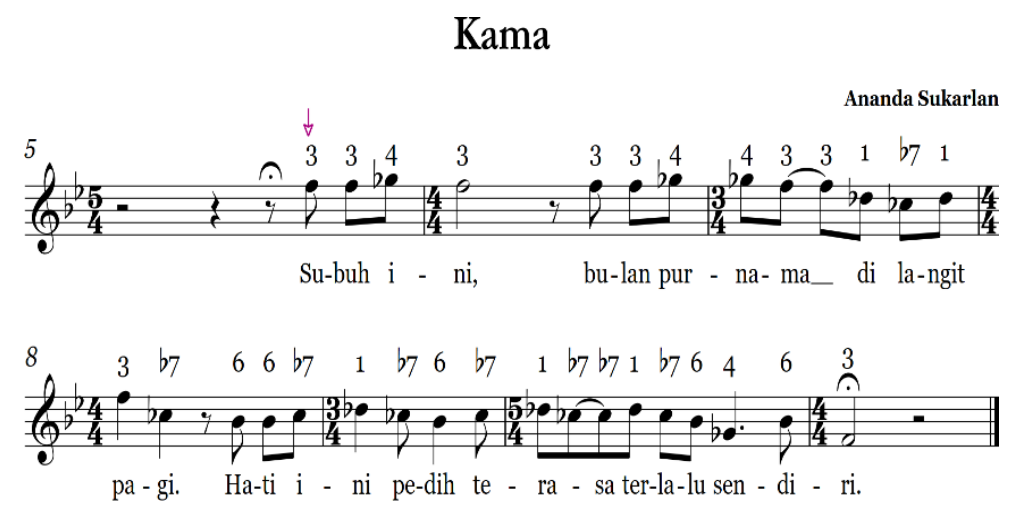

Figure 5: Text Based on Malayu Ilham Poetry

Source: Tembang Puitik Vol 1 (Sukarlan, 2007)

This composition is based on the Malayu Ilham poem entitled Kama. This poem is an expression of losing hope; lonely in solitude; confusion in the meaning of life; and the deep sadness of parting with the family. The period of serving his sentence in a Bangkok prison became a place to produce inspiring poetry works. The 'real' joy may not be as enjoyable as it used to be, but the moment of joy for him was enough when he saw the spider with all its activities in the cell. This is expressed in his poem, entitled Spider's Ballad.

\section{Music Performances as Identity and Promotion of Indonesian Tourist Destinations}

In the past two years (especially during the COVID-19 pandemic), the composer has actively organized virtual performances that are packaged neatly and attractively. His first virtual concert on May 28, 2020 was organized by the Director General of Culture of the Republic of Indonesia. This concert was a challenge for Ananda Sukarlan. The concept of this on-line show 


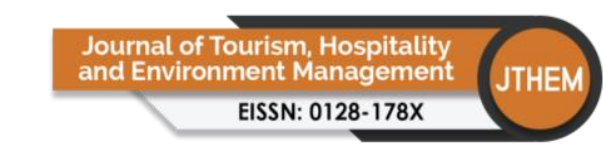

Volume 6 Issue 26 (December 2021) PP. 58-74

DOI 10/35631/JTHEM.626004

is different from a concert on television or in a concert hall. On-line shows can present audiences from various regions or countries with different cultural and linguistic backgrounds. This on-line concert is a new opportunity and challenge for composers to present interesting performances, Ananda Sukarlan said "on-line concerts must still be communicative with other cultures of music because music is a universal language. In addition, today's concert program shows a strong sense of Indonesianness." The first repertoire selection entitled Variation on "Ibu Pertiwi" is a work based on a patriotic song. The meaning of the song Ibu Pertiwi composed by Ismail Marzuki is full of national and archipelago personifications. The composer creatively divides the theme of the song into two parts, this is done as part of the composer's creativity to anticipate themes that are too long, causing 'boredness' and the continuity of variations, generally taking short material as was done by Mozart (2005) in the work 12 Variations on 'Ah, vous dirai-je maman, K.265/300e with a theme of 16 bars in the 2/4 duplet meter and Berkley and Paganini (1986) in the work of 24 Caprices for Solo Violin, Op.1 with a theme of 12 bars in the duplet meter- $2 / 4$.

The Virtual Tribute to BJ Habibie concert which was held on June 25, 2020 was the second virtual concert conducted by Ananda Sukarlan. In particular, the composer raised a specific theme "BJ Habibie" which describes how this figure has provided inspiration and encouragement. He encouraged him to promote Indonesian music by presenting new compositions and providing opportunities for young pianists or musicians who have musical skills to participate in performing the works he composed. Sukarlan (2020) mentions:

\footnotetext{
Currently, I am at the residence of the late former president Habibie (the 3rd President of the Republic of Indonesia Habibi). He was born in 1936, and passed away on September 11, 2019. Today is his 84th birthday and I especially played the Happy Birthday Remix which I composed based on the works of Joy of Man's Desiring Johann Sebastian Bach and the Beach Boys - Lady Linda and then put the Happy Birthday song on it, ...this place has its own history for me because this concert hall is the place where I first met and talked to him, in 2013. On that occasion, Habibie asked me to compose a symphony or chamber music by containing the identity of Indonesian classical music which is new, strong, and easy to teach.
}

Efforts made by composers in introducing 'new' and 'strong' music with the character of Indonesian musical identity are by continuously producing new works; perform it at home and abroad; and facilitating pianists and vocal soloists to take part in competitions. The new works produced are the completion of 34 Rapsodia Nusantara works based on Indonesian musical elements and folk songs from Sabang to Merauke. Rapsodia Nusantara is specially designed with a virtuoso technique and a work that is recommended for closing recitals and music concerts. In addition, Ananda Sukarlan's vocal music works are based on poems by Indonesian poets. Various techniques and the composer's creativity are beautifully presented in the five volumes of Tembang Puitik. 


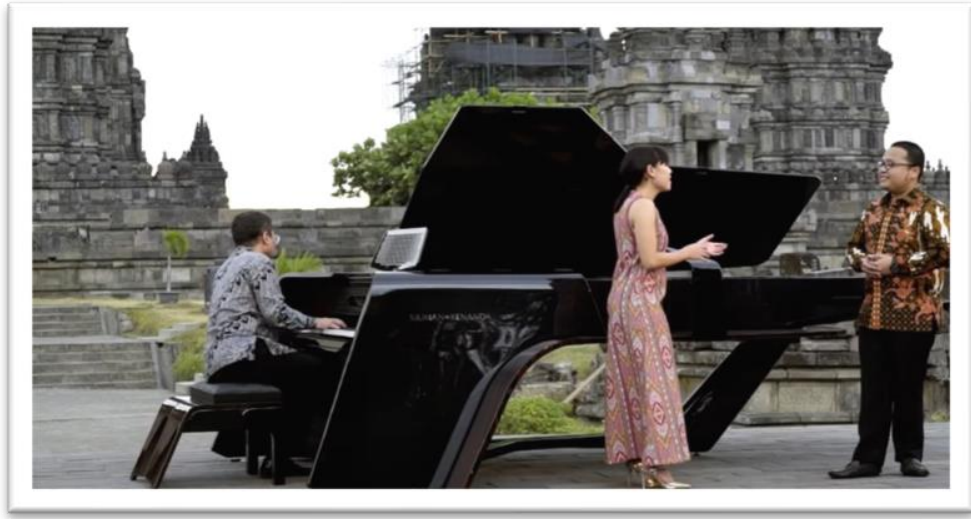

Figure 6: Lokasi Koser Tur Rapsodia Nusantara di Candi Prambanan

Source: Directorate General of Culture (2020)

One of the efforts to popularize his works widely for the wider community is by collaborating with the Ministry of Education and Culture of the Republic of Indonesia. This collaboration provides a great space in introducing Ananda Sukarlan's works and prepares young Indonesian musicians to be pushed forward to take a leading position in demonstrating their expertise in playing the works composed by Ananda Sukarlan. Some of the activities that resulted from this collaboration were musical performances that raised the wealth and glory of the archipelago. This activity is well packaged and emphasizes collaboration between composers and young Indonesian musicians. The inaugural concert of the series "Tour Rapsodia Nusantara" at the historic site of the archipelago was held on 27 September 2020 with the theme "Prambanan A Twilight Tryst Ananda" where Ananda Sukarlan as pianist and composer; Mariska Setiawan as soloist soprano; Widhawan Aryo Praditha as tenor soloist; Sulistya on flute and Nedy Benedict on oboe.

Ananda Sukarlan raised the Javanese philosophy of Urip Iku Urup, which means life is a flame. Life must illuminate, and we must inspire others. The Prambanan temple complex is also adjacent to the Sewu temple where in the 9th century Buddhists and Hindus lived peacefully. This picture must be a picture of society in Indonesia forever. This temple is not only built to praise God or to praise higher beings, but serves as a meeting point for people which can be interpreted as a form of communication not only upwards but also to the surroundings. Ananda Sukarlan also designed this inaugural concert as a form of communication from Indonesia to the rest of the world and because of that, some of Ananda Sukarlan's works were inspired by foreign artists, such as the American poet Emely Dickinson's poems which were composed in the form of oboe and piano. 


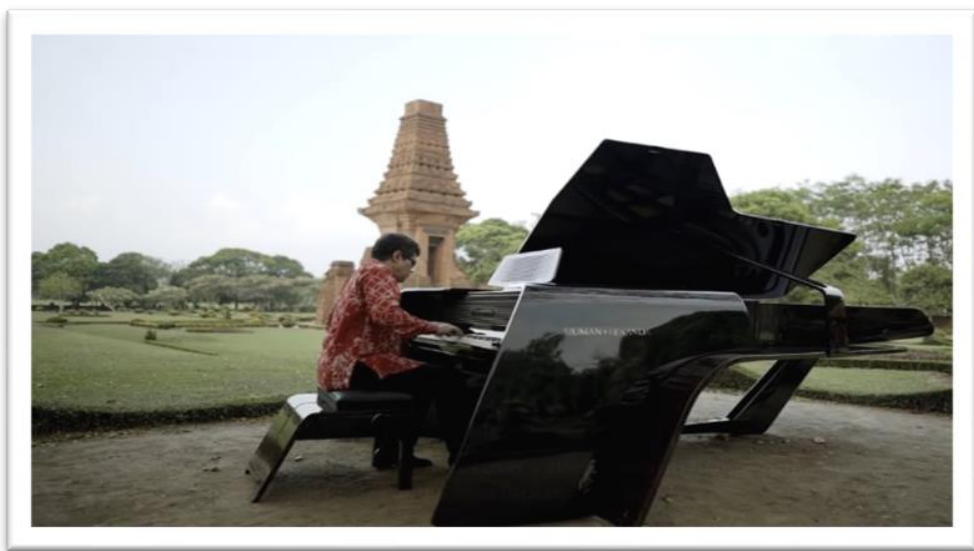

Figure 7: Location of the Majapahit Concert 'The Birth of Nusantara' at the Tikus Temple Petirtaan Site

Source: Directorate General of Culture (2020)

Majapahit "The Birth of Nusantara" is the second concert in the "Rapsodia Nusantara Tour" series which was held on October 20, 2020. This concert was held at Brahu Temple which is located in the Trowulan archaeological site area, built during the 14th century Majapahit era. The Majapahit kingdom for 200 years covered most of Indonesia, so the Majapahit kingdom was the largest kingdom in Indonesia at that time. The Majapahit Kingdom had a big vision "Majapahit become so advanced politically, economically, and of course culturally". According to Ananda Sukarlan, "music at that time was certainly very developed and at that time we still used pentatonic scales. The pentatonic scale is actually still used in many parts of the world. One of my works is entitled Passacaglia which is arranged in semitone, whole tone, third and other semitone intervals. You can hear this Passacaglia which is the basis of a lot of gamelan music because it has ostinato which means repeating bass line."

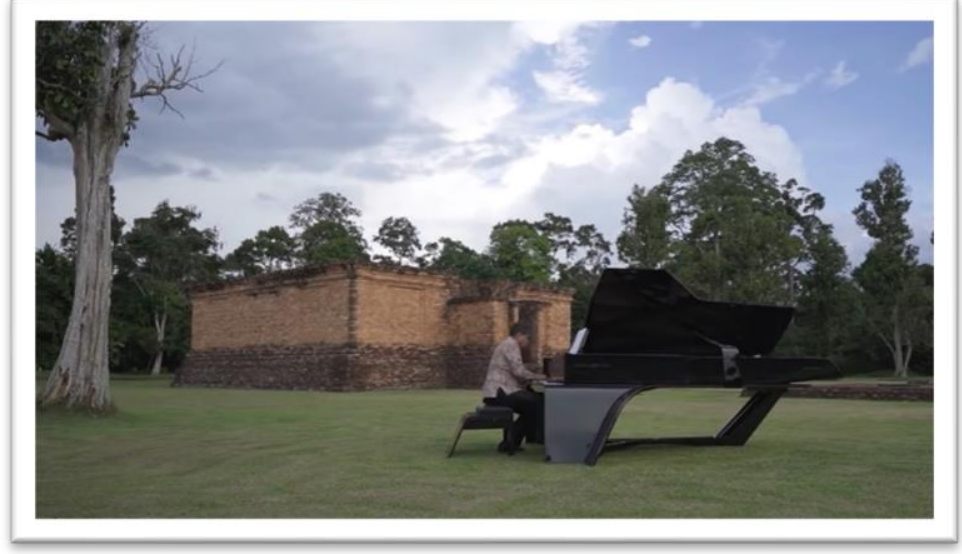

\section{Figure 8: Location of the December in Sriwijaya Concert at Gumpung Muaro Jambi Temple}

Source: Directorate General of Culture (2020)

The next concert was the "December di Sriwijaya" concert which took place at the Gumpung Muaro Jambi Temple. Coinciding with Indonesia's National Mother's Day, this program is a tribute to mothers and women in general. Muaro Jambi in East Sumatra used to be the capital of the oldest kingdom in Indonesia dating back to the 7th to 13th centuries. Jambi is 


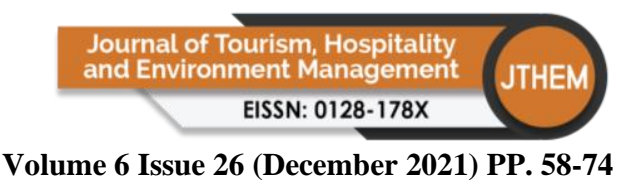

Volume 6 Issue 26 (December 2021) PP. 58-74

DOI 10/35631/JTHEM.626004

also the center of Buddhism in Asia, where religious leaders from countries such as India, China and Nepal come to deepen their knowledge here. According to Agus Widiatmoko (2020) "formerly the Gumpung Muoro Jambi Temple was a place for monks and pandits to study philosophy about Buddhism which is usually devoted to the Monastery, and also a place of worship called Setia Gara. From the 7th to 13th centuries AD, Srivijaya became an educational center comparable to Nalanda in India".

In addition to organizing online concerts, online piano and vocal competitions are two activities that have been carried out in 2020 and 2021. The competition is a means to introduce works to the wider community as well as provide opportunities for young Indonesian musicians to appear in prestigious national events. Due to the COVID-19 pandemic, the Ananda Sukarlan 2020 Piano Competition was held online without compromising on quality, and the invited judges were; Anthony Hartono (Winner of the Ananda Sukarlan Award 2014) and Christine Utomo who have a track record as worldrenowned pianists.

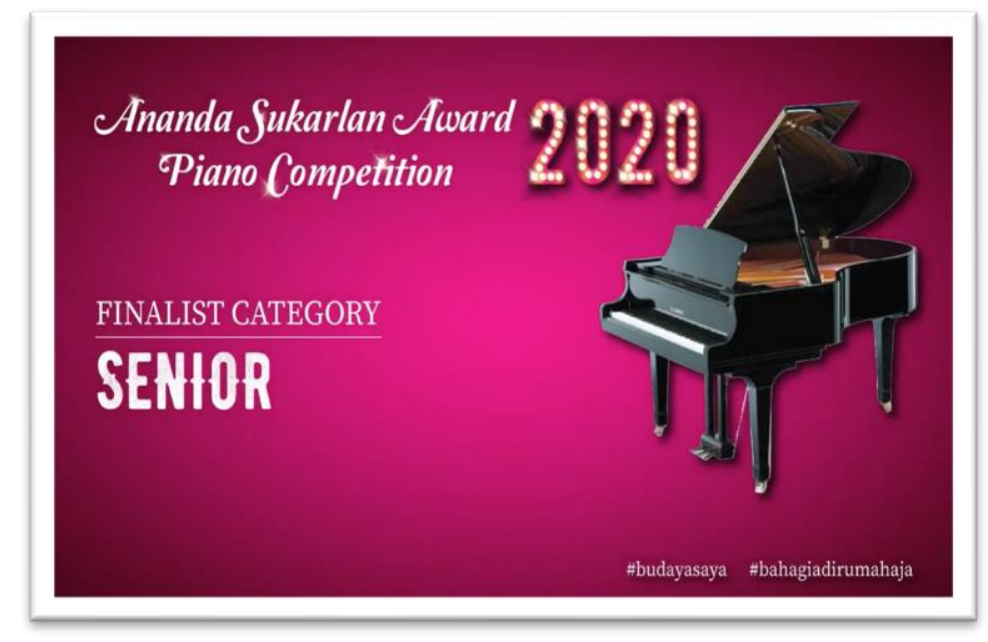

Source: Ananda Sukarlan Center

Figure 9: ASA Piano Competition 2020

This competition was attended by 104 participants and received full support from the Ministry of Education and Culture of the Republic of Indonesia by providing registration fees for each participant who participated. This is done as a form of obtaining superior human resources in the field of art and establishing the identity of classical music in Indonesia. The main winner received a scholarship for a summer course to France sponsored by the Institut Francais d'Indonesie and the other winners were empowered to increase the resilience of Indonesian culture through cultural diplomacy.

The Ananda Sukarlan Poetry Online Competition was held in 2021 and was attended by 30 participants with a jury team consisting of Ananda Sukarlan as composer; Dody Soetanto as baritone; and Mariska Setiawan as soprano. This competition aims to map young talents in the classical vocal field, ensure the sustainability of Indonesian classical vocal music, and provide opportunities for collaboration with Indonesian musician maestro. Ananda Sukarlan's online poetry competition is supported by the Indonesian Creative Industry Cooperative (Koperasi Industri Kreatif Indonesia), along with other creative industry players. 


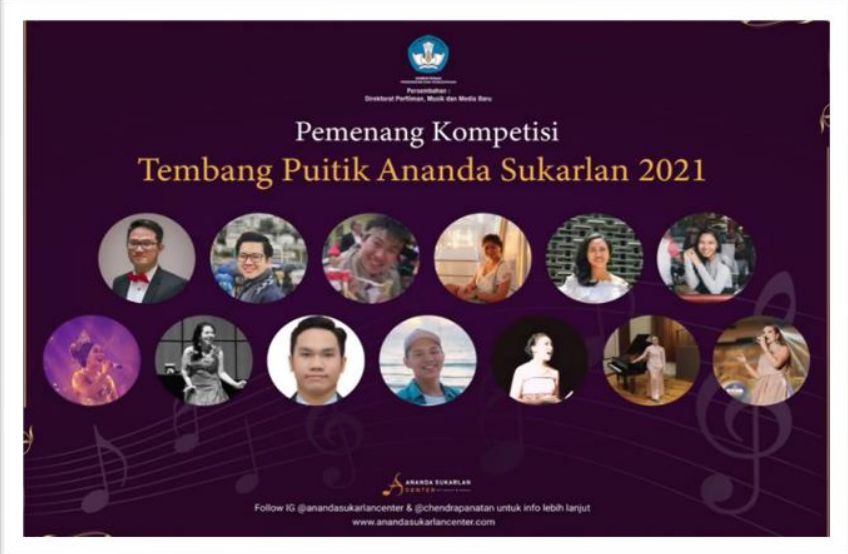

Source: Ananda Sukarlan Center

\section{Figure 10: Tembang Puitik Competition 2021}

\section{Conclusion}

Novelty in the composition of works can also be understood as new approaches and practices used in selecting certain materials, forms, and musical philosophies which then affect the tonality, structure, harmony, texture, and color of the sound. These choices become a space for composers to build national identity by formalizing their compositions in conceptual domains, such as; use of materials or materials sourced from Indonesian idioms and folk songs; and look for appropriate musical methods or structures by always considering the selection of existing musical materials. In addition, the presentation of 'Indonesian classical music' with the background of Indonesia's natural beauty and heritage sites in the past which are full of religious and educational values can be interpreted as a form of promoting Indonesian tourism to the wider community. The strength between the Indonesian musical elements and the location of the presentation further strengthens the meaning of the vocal and piano music delivered because they are in a similar resonance.

\section{References}

Beard, D., \& Gloag, K. (2005). Musicology: The key concepts. London: Routledge, x-xi.

Berkley H, and Paganini, N. (1986). 24 Caprices, Op. 1: Schirmer Library of Classics Volume 1663 Violin Solo. Publisher G. Schirmer, Inc. 1-52.

BPMI Setpres. (2019). Kompas 100 CEO Forum: Destinasi Wisata Baru untuk Penambahan Devisa. https://www.presidenri.go.id/siaran-pers/destinasi-wisata-baru-untukpenambahan-devisa/, accessed on October 25, 2021.

Biro Komunikasi Publik Kementerian PUPR. (2021). Kementerian PUPR Ubah Wajah Labuan Bajo Menjadi Kawasan Wisata Premium Berkelas Dunia, https://pu.go.id/berita/kementerian-pupr-ubah-wajah-labuan-bajo-menjadi-kawasanwisata-premium-berkelas-dunia, accessed on October 26, 2021.

Cheuse, A. (2002). Reading the Archipelago. The Antioch Review, 60(4), 551-567. https://doi.org/10.2307/4614391

Csikszentmihalyi, Mihalyi. (1999). Implications of a Systems Perspective for the Study of Creativity. In Handbook of Creativity, Eds. Robert J. Sternberg. Cambridge: Cambridge University Press.

Direktorat Jenderal Kebudayaan. (2020). Intimate Inspirations with Ananda, https://www.youtube.com/watch?v=JCrYyrAVehc, accessed on 01 July 2021. 


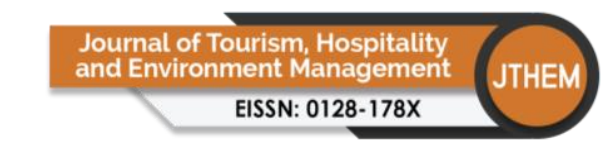

Volume 6 Issue 26 (December 2021) PP. 58-74 DOI 10/35631/JTHEM.626004

Handayani, I. (2021). Keren! Begini Penampakan Labuan Bajo Jadi Wisata Premium. https://www.beritasatu.com/gaya-hidup/835531/a-begini-penampakan-labuan-bajojadi-wisata-premium, accessed on 26 October 2021.

Hargreaves, D., Miell, D., \& Macdonald, R. (2002). What are musical identities, and why are they important? In Musical Identities. Oxford University Press, 11.

Henson, F.G. (1989). Historical development and attendant problems of cultural resource management in the Philippines. In H. Cleere (ed.), Archaeological Heritage Management in the Modern World, pp. 109-17. London: Unwin Hyman.

Jarir and Khairiah. (2018). Sejarah Nusantara: Perspektif Geologis, Zoologis dan Etnografis. NUSANTARA: Journal for Southeast Asian Islamic Studies, 14(2), 126-135. http://dx.doi.org/10.24014/nusantara.v14i2.7153

Mohammed, S.F.S. (2016). The History and Development of Lagu Seriosa in the Context of Musical Nationalism in Indonesia. Doctor of Philosophy at Monash University.

Mozart, A.W. (2005). Ah, vous dirai-je Maman". Zwölf Variationen in C für Klavier. / Twelve Variations in C major for Piano. KV 265 (300e). Bärenreiter: Kassel, 1-13.

Myles, K. (1989). Cultural resource management in Sub-Saharan Africa: Nigeria, Togo and Ghana. In H. Cleere (ed.), Archaeological Heritage Management in the Modern World, pp. 118-27. London: Unwin Hyman.

Parekh, B. (2007). Reasoned Identities: A Committed Relationship. In M. WetherellM. Laflèche, \& R. Berkeley (Eds.), Identity, ethnic diversity and community cohesion (pp. 130-135). SAGE Publications Ltd, https://www.doi.org/10.4135/9781446216071.n12

Petriella, Y. (2020). Pembangunan Hunian di Kawasan Danau Toba Dipacu, Ini Progresnya", https://ekonomi.bisnis.com/read/20201014/47/1305151/pembangunan-hunian-dikawasan-danau-toba-dipacu-ini-progresnya, accessed on 26 October 2021.

Rasmindarya, R. I. (1999). The Evolution of the Indonesian Art Song: A Historical Study of a New Musical Form in the Indonesian Music Repertoire. New York University.

Simanjuntak, L.L., Simatupang, L.L., and Ganap, V. (2019). Indonesian Piano Composition in History of Music. Conference: Proceedings of the First Nommensen International Conference on Creativity \& Technology, NICCT, 20-21 September 2019, Medan, North Sumatera, Indonesia. https://doi: 10.4108/eai.20-9-2019.2296601

Sukarlan, A. (2011) Rapsodia Nusantara 1-5. Copyright (C) Ananda Sukarlan, 1-9.

Timothy, D.J. and Boyd, S.W. (2003). Heritage Tourism. Harlow: Prentice Hall.

Tjaroko, W.S. (2007). Sejarah Perkembangan Lagu Seriosa Indonesia. Tesis untuk mendapatkan derajat sarjana S-2 pada Program Studi Pengkajian Seni Pertunjukan dan Seni Rupa Universitas Gadjah Mada Yogyakarta.

van der Kroef, J. M. (1951). The Term Indonesia: Its Origin and Usage. Journal of the American Oriental Society, 71(3), 166-171. https://doi.org/10.2307/595186

Williams, R. (1988). Keywords: A Vocabulary of Culture and Society. London: Fontana.

Yunita, A.T. (2012). Kebangkitan Nasionalisme Eropa dan Pengaruhnya Terhadap Perkembangan Lagu Seriosa Indonesia. Tesis untuk mendapatkan derajat sarjana S-2 pada Program Studi Pengkajian Seni Pertunjukan dan Seni Rupa Universitas Gadjah Mada Yogyakarta, Universitas Gadjah Mada.

Zhang, D. (1992). Protecting China's rich heritage of cultural relics. China Today, 41 (6): 1417.

(2020). "Konser Tur Nasional 2020 Rapsodia Nusantara dan Kejayaan Nusantara", https://www.youtube.com/watch?v=tPZuM7E7zb0, accessed on 02 July 2021. 
Volume 6 Issue 26 (December 2021) PP. 58-74

(2020). "Majapahit The Birth of Nusantara",
https://www.youtube.com/watch?v=FARK3h6yqaw, accessed on 03 July 2021.

(2020).

Konser

December

in

Sriwijaya,

https://www.youtube.com/watch?v=c1tu82vyhu4, accessed on 04 July 2021.

(2020). Talk show Situs Muaro Jambi "Kejayaan SRIWIJAYA", https://www.youtube.com/watch?v=dtpCjanDMus, accessed on 04 July 2021.

. (2021). Pembangunan Infrastruktur di Kawasan Wisata Danau Toba Capai 97,6\%. https://www.beritasatu.com/nasional/835057/pembangunan-infrastruktur-dikawasan-wisata-danau-toba-capai-976, accessed on 26 October 2021.

. (2019). Discourse on Indonesian Piano Composition for Music Education. Conference: Proceedings of the Social Sciences, Humanities and Education Conference (SoSHEC 2019). https://doi.org/10.2991/soshec-19.2019.66

. (2021). Indonesian Composer's Piano Work in the Piano Education Curriculum. International Journal of Education, Culture and Society. Vol. 6, No. 3, 2021, pp. 85-91. https://doi: 10.11648/j.ijecs.20210603.13 . (2007) Tembang Puitik Vol 1. Copyright (C) Ananda Sukarlan, 44-48.

(2020). "Tribute to B.J. Habibie by Ananda Sukarlan's Chamber", https://www.youtube.com/watch?v=yvTSC1L232U, accessed on 02 July 2021. 